\title{
Analisis Pengelompokkan Persediaan Jenis Bahan Baku Rotan dengan Menggunakan Metode ABC
}

\author{
M. Sayuti ${ }^{1}$ \\ ${ }^{1}$ Jurusan Teknik Industri, Fakultas Teknik, Univ Malikussaleh, Aceh Utara-NAD \\ tgk_sayuti@yahoo.co.uk
}

\begin{abstract}
PT Bumi Selawah kab.pidie is an industrial company that was founded under perhaps the industry kab.pidie engaged in furniture products are made from rattan. In a production system the company has not classifying products which require priority highest amount of raw material. This is evident from observations in 2014-2015. Where the supply of raw materials is different each year. In 2014 the company supplying raw rattan by 20 tons, which is used only 12 tons, in 2015 the company supplied 10 tons, which is used only 9 tons. The results showed that the total percentage of absorption of funds amounting to 99.6\%, where the cumulative percent of items of goods, Rattan Semanow (24-29) 11.11\%, Rattan Semanow (40) 22.22\%, Rattan Semanow (35-39) 33.33\%, Rattan Semanow (18-23) 44.44\%, 55.55\% Track Rattan, Rattan Fega 66.66\%, Semanow (30-34) 77.77\%, Semanow (15-17) 88, Rattan Semanow 88\% and 99.99\%. There are 4 items that belong to class $\mathrm{A}$, which supplies high-end, inventories are valued are classified in class $\mathrm{B}$, and supplies the low value belongs to the class $\mathrm{C}$ so that the company can determine how much cane is needed for each category of the classification of the raw materials of rattan these, and order can be made as needed.
\end{abstract}

Keywords: Inventory, ABC method, Rattan

\section{PENDAHULUAN}

PT Bumi Selawah kab.pidie merupakan sebuah perusahaan industri yang berdiri dibawah naugan dinas industri kab.pidie yang bergerak di bidang produk mebel yang berbahan dasar rotan. Dalam sistem produksinya perusahaan belum memiliki pengendalian persediaan yang memadai, artinya perusahaan belum mengelompokkan produk mana yang memerlukan prioritas jumlah bahan baku terbanyak. Hal ini terbukti dari hasil pengamatan pada tahun 2014-2015. Dimana pasokan bahan baku berbeda-beda tiap tahunnya. Tahun 2014 perusahaan memasok bahan baku rotan sebesar 20 ton, yang terpakai hanya 12 ton, Tahun 2015 perusahaan memasok 10 ton, yang tepakai hanya 9 ton. Sedangkan tahun 2016 belum ada pasokan data dari perusahaan, artinya perusahaan memasok bahan baku berdasarkan kebutuhan dan belum memiliki jumlah mengenai perkiraan pemesanan yang akan dilakukan. Jika hal ini terus terjadi dapat mengakibatkan kerugiaan yang cukup besar pada perusahaan, sehingga perlu pembenahan dalam persediaan bahan baku. Untuk menyelesaikan persoalan tersebut maka dilakukan analisis pengelompokkan persediaan dengan menggunakan metode $A B C$ agar perusahaan dapat mengetahui prioritas jumlah persediaan jenis bahan baku sesuai kebutuhan.

\section{LANDASAN TEORI}

\subsection{Pengertian sistem persediaan}

Sistem persediaan adalah serangkaian kebijaksanaan dan pengendaliaan yang memonitor tingkat persediaan yang bertuan untuk menetapkan dan meminjam tersedianya sumber daya alam kulitas dan waktu yang tepat. Oleh karena itu, sasaran akhir dari sistem 
persediaan adalah menghasilkan keputusan tingkat persediaan, yang mengembangkan tujuan diadakannya persediaan adalah untuk meminimumkan total biaya melalui penentuan berapa banyak dan kapan pemesanan dilakukan secara optimal[1].

\subsection{Klarifikasi persediaan}

Setiap jenis jenis persediaan memiliki karakteristik khusus tersedia dan cara pengelolaannya yang berbeda. Menurut jenisnya persediaan dapat diklarifikasikan sebagai berikut[2]:

1. Persediaan bahan mentah (raw material), yaitu persediaan barang-barang berwujud seperti baja, kayu dan komponen-komponen lainnya yang dingunakan dalam proses produksi. Bahan mentah dapat diperoleh dari sumber-sumber alam atau dibeli dari para suplier atau di buat sendiri oleh perusahaan untuk digunakan oleh proses produksi selanjutnya.

2. Persediaan komponen-komponen rakitan (puchesed part/componencts), yaitu persediaan barang-barang yang terdiri dari komponen-komponen yang diperoleh dari perusahaan lain, di mana secara langsung dapat dirakit menjadi suatu produk.

3. Persediaan bahan baku atau penolong (supplies), yaitu persediaan barang-barang yang diperlukan dalam proses produksi, tetapi tidak merupakan bagian atau komponen barang jadi.

4. Persediaan bahan dalam proses (work in process), yaitu persediaan barang-barang yang merupakan keluaran dari tiap-tiap bagian dalam proses produksi atau yang telah diolah menjadi suatu bentuk, tetapi masih diproses lebih lanjut menjadi barang jadi.

5. Persediaan barang jadi (finished goods), yaitu persediaan barang-barang yang telah selesai diproses atau diolah dalam pabrik dan siap untuk dijual atau dikirim kepada pelanggan.

\subsection{Biaya-biaya yang dibutuhkan dalam persediaan}

Tujuan dari manajemen persediaan adalah memiliki persediaan dalam jumlah yang tepat, pada waktu yang tepat dan dengan biaya yang rendah. Karna itu, kebanyakan model-model persediaan menjadikan biaya sebagai parameter dalam mengambil keputusan. Biaya dalam sistem persediaan secara umum dapat diklarifikasikan sebagai berikut[3]:

a. Biaya pembelian

Biaya pembelian dari suatu item adalah harga pembelian setuiap unit item jika item tersebut berasar dari sumber-sumber ekternal, atau biaya produksi oleh perusahaan atau diproduksi sendiri oleh perusahaan. Biaya pembeliaan ini bias bervariasi untuk berbagai ukuran pemesanan bila pemasok menawarkan potongan harga untuk ikuran pemesanan yang lebih besar.

b. Biaya Pengadaan

Biaya pengadaan dibagi atas 2 jenis sesuai dengan asal-usul barang, yaitu biaya pemesanan (orderring cost) bila biaya yang diperlukan diperoleh dari pihak luar (supplier) dan biaya pembuatan (setup cost) bila barang diperoleh dengan produksi sendiri.

c. Biaya penyimpanan (manufacturing atau setup cost)

Biaya ini timbul bila bahan-bahan tidak dibeli, tetapi diproduksi sendiri "dalam pabrik” perusahaan menghadapi biaya penyiapan (setup cost) untuk memproduksi komponen tertentu. Biaya-biaya ini terdiri dari:

- Biaya-biaya mesin mengangggur

- Biaya persiapan tenaga kerja langsung.

- Biaya penjadwalan

- Biaya kekurangan persediaan

- Biaya ekspedisi dan sebagainya 
Dari semua Biaya-biaya berhubungan dengan tingkat persediaan, biaya kekurangan persediaan (shortage cost) adalah paling sulit diperkirakan. Biaya kekurangan persediaan adalah semua biaya yang timbul apabila persediaan tidak tersedia di gudang ketika dibutuhkan untuk produksi atau ketika langsung memintanya. Biaya yang dikaitkan dengan biaya kekurangan persediaan meliputi[4] yaitu biaya penjualan atau permintaan yang hilang, kehilangan langganan, biaya pemesanan khusus, biaya ekspedisi, selisih harga, terganggunya operasi dan tambahan pengeluaran kegiatan manajerial dan sebagainya.

\subsection{Metode Analisis ABC}

Pada umumnya persediaan terdiri dari berbagai jenis barang yang sangat banyak jumlahnya. Masing-masing jenis barang membutuhkan analisis tersendiri untuk mengetahui besarnya order size dan order point. Namun demikian harus kita sadari bahwa berbagai macam jenis barang yang ada dalam persediaan tidak seluruhnya memiliki tingkat prioritas yang sama. Sehingga untuk mengetahui jenis-jenis barang mana saja yang perlu mendapatkan prioritas, kita dapat menggunakan amalisa ABC. Analisis ABC ini dapat mengklarifikasikan seluruh jenis barang berdasarkan tingkat kepentingannya[5].

Analisa ABC merupakan langkah pertama dalam usaha untuk mendapatkan penanganan terhadap situasi persediaan. Penerapan prinsip ABC terhadap penanganan persediaan melibatkan[6]:

A. Pengklasifikasian item persediaan pada basis kepentingan relatif.

Penetapan kendali penanganan yang berbeda terhadap klasifikasi yang berbeda dimana derajat pengendalian disesuaikan dengan tingkat kepentingan setiap klasifikasi.

B. Analisa $\mathrm{ABC}$ dilakukan dengan menggunakan kriteria volume biaya tahunan dengan langkah-langkah sebagai berikut:

a. Penentuan penggunaan tahunan setiap item dalam persediaan.

b. Mengalikan penggunaan tahunan setiap item dengan biaya setiap item untuk mendapatkan total biaya penggunaan tahunan setiap item.

c. Menjumlahkan total biaya penggunaan tahunan seluruh item untuk menentukan pengeluaran persediaan tahunan agregat.

d. Bagi total biaya penggunaan tahunan setiap item dengan pengeluaran persediaan tahunan agregat untuk mendapatkan persentase penggunaan total setiap item.

e. Daftarkan item-item tersebut dalam urutan tingkat atas dasar persentase pengunaan agregat.

f. Uji distribusi penggunaan tahunan dalam kelompok item dasar persentase penggunaan tahunan.

Dari hasil analisis ini akan didapatkan klasifikasi item investor kedalam tiga kelas, yakni kelas A, kelas B, kelas C. Kelas A yang mendapat perhatian terdiri dari item yang memiliki volume biaya sekitar $75 \%$ sampai $80 \%$ dari seluruh biaya material dengan hanya $15 \%$ sampai $20 \%$ dari volum item.

Pada prinsipnya analisa ABC ini adalah mengklasifikasikan jenis barang yang didasarkan atas tingkat investasi tahunan yang terserap di dalam persediaan investor pada setiap jenis barang.

Diagram pareto disusun berdasarkan atas persentase kumulatif penyerapan dana dan persentase jenis dari barang yang dikelola. Untuk keperluan penyusunan diagram pareto di perlukan data dasar sebagai berikut:

a. Jenis barang yang di kelola.

b. Jumlah pemakaian tiap jenis barang (biasanya selama satu tahun)

c. Harga satuan barang 
Untuk mengambarkan diagram pareto dan memiliki barang atas beberapa katagori dilakukan dengan cara sebagai berikut[3]:

1. Hitung jumlah penyerapan dana untuk setiap jenis barang $\left(M_{i}\right)$ yaitu dengan mengendalikan antara jumlah pemakaian tiap jenis barang $\left(D_{i}\right)$ dengan harga suatu barang $\left(P_{i}\right)$, secara matematis dapat di nyatakan :

$M_{i}=D_{i} \times P_{i}$

2. Hitung jumlah total penyerapan dana untuk semua jenis barang

3. Hitung persentase penerapan dana untuk semua jenis barang

4. Hitung jumblah total penyerapan dana untuk semua jenis barang $\left(P_{i}\right) P_{i}=D_{i} X P_{i}$

5. Hitung persentase penyerapan dana untuk setiap jenis barang

6. Hitung persentase setiap jenis item

$$
I_{i}=\frac{1}{N} \times 100 \% ; \text { dimana } \mathrm{N} \text { jumlah jenis item barang. }
$$

7. Urutkan persentase penyerapan dana sesuai dengan besarnya persentase penyerapan dana, dimulai dari persentase penyerapan dana dari terbesar sampai terkecil.

8. Hitung nilai komulatif persentase penyerapan dana dan nilai kumulatif persentase jenis barang berdasarkan atas urutan yang diperoleh.

9. Tentukan katagori bahan, yaitu:

Katagori A (80-20):

Terdiri dari jenis barang yang menyerap dana sekitar $80 \%$ dari seluruh modal yang disediakan untuk investori dan jumlah jenis barang sekitar $20 \%$ dari semua jenis barang yang dikelola.

Katagori B (15-30):

Terdiri dari jenis barang yang menyerap dana sekitar 15\% dari seluruh modal yang disediakan untuk investori (sesudah katagori A) dan jumlah jenis barangnya sekitar $30 \%$ dari semua jenis barang yang dikelola.

Katageri C (5-50):

Terdiri dari jenis barang yang menyerap dana hanya sekitar 5\% dari seluruh modal yang disediakan untuk investori (yang tidak termasuk katagori A dan B) dan jumlah jenis barangnya sekitar 50\% dari semua jenis barang yang dikelola.

\section{METODOLOGI PENELITIAN}

Pada penelitian ini metode yang digunakan adalahh metode ABC yaitu mengelompokkan jenis produk sesuai dengan persentase kebutuhannya.

\subsection{Pengumpulan data}

Data mengenai persediaan bahan baku rotan, dapat dilihat pada Tabel $1 \mathrm{~s} / \mathrm{d} 9$.

Tabel 1. Data persediaan dan harga Rotan Lacak

\begin{tabular}{|c|c|c|r|}
\hline Bulan & Jumlah Persediaan & Satuan & \multicolumn{1}{c|}{ Harga } \\
\hline Januari & 200 & Kilo & Rp. 1.600 .000 \\
\hline Februari & 150 & Kilo & Rp. 1.200 .000 \\
\hline Maret & 100 & Kilo & Rp. 800.000 \\
\hline April & 300 & Kilo & Rp. 2.400 .000 \\
\hline Mei & 120 & Kilo & Rp. 960.000 \\
\hline Juni & 300 & Kilo & Rp. 2.400 .000 \\
\hline Juli & 170 & Kilo & Rp. 1.360 .000 \\
\hline Agustus & 160 & Kilo & Rp. 1.280 .000 \\
\hline September & 190 & Kilo & Rp. 1.520 .000 \\
\hline Oktober & 100 & Kilo & Rp. 800.000 \\
\hline November & 120 & Kilo & Rp. 960.000 \\
\hline
\end{tabular}




\begin{tabular}{|c|c|c|c|}
\hline Desember & 130 & Kilo & Rp. 1.040.000 \\
\hline Jumlah & 2040 & Kilo & Rp. 4.800.000 \\
\hline \multicolumn{2}{|c|}{ Rata-Rata } & Rp. 2.666.666 \\
\hline
\end{tabular}

Tabel 2. Data persediaan dan harga Rotan Semanow.

\begin{tabular}{|c|c|c|r|}
\hline Bulan & Jumlah Persediaan & Satuan & \multicolumn{1}{c|}{ Harga } \\
\hline Januari & 100 & Kilo & Rp. 200.000 \\
\hline Februari & 500 & Kilo & Rp. 1.000 .000 \\
\hline Maret & 300 & Kilo & Rp. 600.000 \\
\hline April & 300 & Kilo & Rp. 600.000 \\
\hline Mei & 200 & Kilo & Rp. 400.000 \\
\hline Juni & 200 & Kilo & Rp. 400.000 \\
\hline Juli & 200 & Kilo & Rp. 400.000 \\
\hline Agustus & 100 & Kilo & Rp. 200.000 \\
\hline September & 150 & Kilo & Rp. 300.000 \\
\hline Oktober & 150 & Kilo & Rp. 300.000 \\
\hline November & 90 & Kilo & Rp. 180.000 \\
\hline Desember & 200 & Kilo & Rp. 400.000 \\
\hline Jumlah & 2490 & Kilo & Rp. 4.890 .000 \\
\hline \multicolumn{2}{|c|}{ Rata-Rata } & Rp. 407.500 \\
\hline
\end{tabular}

Tabel 3. Data persediaan dan harga Rota Slimit.

\begin{tabular}{|c|c|c|r|}
\hline Bulan & Jumlah Persediaan & Satuan & Harga \\
\hline Januari & 50 & Kilo & Rp. 1.100 .000 \\
\hline Februari & 80 & Kilo & Rp. 1.760 .000 \\
\hline Maret & 80 & Kilo & Rp. 1.760 .000 \\
\hline April & 100 & Kilo & Rp. 2.200 .000 \\
\hline Mei & 170 & Kilo & Rp. 3.740 .000 \\
\hline Juni & 120 & Kilo & Rp. 2.640 .000 \\
\hline Juli & 125 & Kilo & Rp. 2.750 .000 \\
\hline Agustus & 200 & Kilo & Rp. 4.400 .000 \\
\hline September & 110 & Kilo & Rp. 2.420 .000 \\
\hline Oktober & 120 & Kilo & Rp. 2.640 .000 \\
\hline November & 100 & Kilo & Rp. 2.200 .000 \\
\hline Desember & 90 & Kilo & Rp. 1.980 .000 \\
\hline Jumlah & 1345 & Kilo & RP. 29.600 .000 \\
\hline \multicolumn{2}{|c|}{ Rata-rata } & & Rp. 2.466 .670 \\
\hline
\end{tabular}

Tabel 4. Data persediaan dan harga Rotan smanow (15-17).

\begin{tabular}{|c|c|c|c|}
\hline Bulan & Jumlah Persediaan & Satuan & Harga \\
\hline Januari & 200 & Batang & Rp. 400.000 \\
\hline Februari & 400 & Batang & Rp. 800.000 \\
\hline Maret & 200 & Batang & Rp. 400.000 \\
\hline April & 200 & Batang & Rp. 400.000 \\
\hline
\end{tabular}




\begin{tabular}{|c|c|c|r|} 
Mei & 300 & Batang & Rp. 600.000 \\
\hline Juni & 100 & Batang & Rp. 200.000 \\
\hline Juli & 120 & Batang & Rp. 240.000 \\
\hline Agustus & 100 & Batang & Rp. 200.000 \\
\hline September & 300 & Batang & Rp. 600.000 \\
\hline Oktober & 200 & Batang & Rp. 400.000 \\
\hline November & 400 & Batang & Rp. 800.000 \\
\hline Desember & 250 & Batang & Rp. 500.000 \\
\hline Jumlah & 2760 & Batang & Rp. 5.540 .000 \\
\hline & Rata-Rata & & Rp. 461.670 \\
\hline
\end{tabular}

Tabel 5. Data persediaan dan harga Rotan Semanow (18-23).

\begin{tabular}{|c|c|c|r|}
\hline Bulan & Jumlah Persediaan & Satuan & Harga \\
\hline Januari & 100 & Batang & Rp. 750.000 \\
\hline Februari & 400 & Batang & Rp. 3.300 .000 \\
\hline Maret & 500 & Batang & Rp. 3.750 .000 \\
\hline April & 300 & Batang & Rp. 2.250 .000 \\
\hline Mei & 200 & Batang & Rp. 1.500 .000 \\
\hline Juni & 200 & Batang & Rp. 1.500 .000 \\
\hline Juli & 300 & Batang & Rp. 2.250 .000 \\
\hline Agustus & 320 & Batang & Rp. 2.400 .000 \\
\hline September & 200 & Batang & Rp. 1.500 .000 \\
\hline Oktober & 400 & Batang & Rp. 3.300 .000 \\
\hline November & 200 & Batang & Rp. 1.500 .000 \\
\hline Desember & 200 & Batang & Rp. 1.500 .000 \\
\hline Jumlah & 3200 & Batang & Rp. 2.203 .300 \\
\hline \multicolumn{2}{|c}{} & Rp. 1.850 .275 \\
\hline
\end{tabular}

Tabel 6. Data persediaan dan harga Rotan Semanow (24-29).

\begin{tabular}{|c|c|c|c|}
\hline Bulan & Jumlah Persediaan & Satuan & Harga \\
\hline Januari & 500 & Batang & Rp. 5.250 .000 \\
\hline Februari & 240 & Batang & Rp. 2.520 .000 \\
\hline Maret & 220 & Batang & Rp. 2.310 .000 \\
\hline April & 100 & Batang & Rp 1.050 .000 \\
\hline Mei & 200 & Batang & Rp. 2.100 .000 \\
\hline Juni & 300 & Batang & Rp. 3.150 .000 \\
\hline Juli & 350 & Batang & Rp. 3.675 .000 \\
\hline Agustus & 400 & Batang & Rp. 4.200 .000 \\
\hline September & 400 & Batang & Rp. 4.200 .000 \\
\hline Oktober & 300 & Batang & Rp. 3.150 .000 \\
\hline November & 200 & Batang & Rp. 2.100 .000 \\
\hline Desember & 200 & Batang & Rp. 2.100 .000 \\
\hline Jumlah & 5350 & Batang & Rp. 35.805.000 \\
\hline
\end{tabular}


Tabel 7. Data persediaan dan harga Rotan Semanow (30-34).

\begin{tabular}{|c|c|c|r|}
\hline Bulan & Jumlah Persediaan & Satuan & Harga \\
\hline Januari & 200 & Batang & Rp. 2.400 .000 \\
\hline Februari & 200 & Batang & Rp. 2.400 .000 \\
\hline Maret & 300 & Batang & Rp. 3.600.000 \\
\hline April & 200 & Batang & Rp. 2.400 .000 \\
\hline Mai & 200 & Batang & Rp. 2.400 .000 \\
\hline Juni & 400 & Batang & Rp. 4.800 .000 \\
\hline Juli & 420 & Batang & Rp. 5.040 .000 \\
\hline Agustus & 250 & Batang & Rp. 3.000 .000 \\
\hline September & 100 & Batang & Rp. 1.200 .000 \\
\hline Oktober & 110 & Batang & Rp. 1.320 .000 \\
\hline November & 200 & Batang & Rp. 2.400 .000 \\
\hline Desember & 200 & Batang & Rp. 2.400 .000 \\
\hline Jumlah & 2780 & Batang & Rp. 13.360 .000 \\
\hline \multicolumn{2}{|c|}{ Rata-rata } & Rp. 1.113 .333 \\
\hline
\end{tabular}

Tabel 8. Data Persediaan dan harga Rotan Semanow (35-39).

\begin{tabular}{|c|c|c|r|}
\hline Bulan & Jumlah Persediaan & Satuan & Harga \\
\hline Januari & 300 & Batang & Rp. 4.500 .000 \\
\hline Februari & 350 & Batang & Rp. 5.250 .000 \\
\hline Maret & 330 & Batang & Rp. 4.950 .000 \\
\hline April & 250 & Batang & Rp. 3.750 .000 \\
\hline Mai & 350 & Batang & Rp. 3.750.000 \\
\hline Juni & 200 & Batang & Rp. 3.000.000 \\
\hline Juli & 200 & Batang & Rp. 3.000 .000 \\
\hline Agustus & 110 & Batang & Rp. 1.650 .000 \\
\hline September & 120 & Batang & Rp. 1.800 .000 \\
\hline Oktober & 200 & Batang & Rp. 3.000.000 \\
\hline November & 200 & Batang & Rp. 3.000.000 \\
\hline Desember & 220 & Batang & Rp. 3.300.000 \\
\hline Jumlah & 2830 & Batang & Rp. 40.950 .000 \\
\hline \multicolumn{2}{|c}{ Rata-rata } & & Rp. 3.412.300 \\
\hline
\end{tabular}

Tabel 9. Data persediaan dam harga Rotan Semanow (40).

\begin{tabular}{|c|c|c|c|}
\hline Bulan & Jumlah Persediaan & Satuan & Harga \\
\hline Januari & 300 & Batang & Rp. 4.800 .000 \\
\hline Februari & 350 & Batang & Rp. 5.600 .000 \\
\hline Maret & 200 & Batang & Rp. 3.200 .000 \\
\hline April & 200 & Batang & Rp. 3.200 .000 \\
\hline Mai & 150 & Batang & Rp. 2.400 .000 \\
\hline
\end{tabular}




\begin{tabular}{|c|c|c|r|} 
Juni & 260 & Batang & Rp. 4.160 .000 \\
\hline Juli & 200 & Batang & Rp. 3.200 .000 \\
\hline Agustus & 100 & Batang & Rp. 1.600 .000 \\
\hline September & 200 & Batang & Rp. 3.200 .000 \\
\hline Oktober & 300 & Batang & Rp. 4.800 .000 \\
\hline November & 400 & Batang & Rp. 6.400 .000 \\
\hline Desember & 250 & Batang & Rp. 3.400 .000 \\
\hline Jumlah & 2910 & Batang & Rp. 46.660 .000 \\
\hline \multicolumn{2}{|c|}{ Rata-rata } & Rp. 3.888.333 \\
\hline
\end{tabular}

Sumber PT.Bumi Selawah Kab. Pidie.

\subsection{Pengolahan data}

Kualitas pemakaian jenis rotan (Di) dan harga satuan (pi) dapat dilihat pada Tabel 10, sedangkan rekapitulasi nilai penyerapan dana dan \% penyerapan dana dapat dilihat pada Tabel 11.

Tabel 10. Data kualitas pemakaian dan harga satuan.

\begin{tabular}{|r|c|c|c|r|}
\hline No. & Jenis Barang & Satuan & $\begin{array}{c}\text { Kualitas } \\
\text { Pemakaian (Di) }\end{array}$ & $\begin{array}{c}\text { Harga Satuan } \\
\text { (pi)(Di) }\end{array}$ \\
\hline 1 & 2 & 3 & 4 & 5 \\
\hline 1 & Rotan Lacak & Kilo & 2040 & 2.666 .666 \\
\hline 2 & Rotan Semanow & Kilo & 2490 & 407.500 \\
\hline 3 & Rotan fega & Kilo & 1345 & 2.466 .670 \\
\hline 4 & Rotan Semanow 15-17 & Batang & 2760 & 461.670 \\
\hline 5 & Rotan Semanow 18-23 & Batang & 3200 & 1.850 .275 \\
\hline 6 & Rotan semanow 24-29 & Batang & 5350 & 2.983 .750 \\
\hline 7 & Rotan Semanow 30-34 & Batang & 2780 & 1.113 .333 \\
\hline 8 & Rotan Semanow 35-39 & Batang & 2830 & 3.412 .300 \\
\hline 9 & Rotan Semanow 40 & Batang & 2910 & 3.888 .333 \\
\hline
\end{tabular}

Tabel 11. Rekapitulasi nilai penyerapan dana dan \% penyerapan dana.

\begin{tabular}{|c|c|c|c|c|}
\hline No & Jenis barang & Satuan & $\begin{array}{c}\text { Nilai Penyerapan Dana } \\
(\text { Mi)(Rp) }\end{array}$ & \% Penyerapan Dana \\
\hline 1 & 2 & 3 & 6 & 7 \\
\hline 1 & 2 & Kilo & $5,439,998,640$ & 9.5 \\
\hline 2 & 2 & Kilo & $1,014,675,000$ & 1.7 \\
\hline 3 & 2 & Kilo & $3,317,671,150$ & 5.8 \\
\hline 4 & 2 & Batang & $1,274,209,200$ & 2.2 \\
\hline 5 & 2 & Batang & $5,920,880,000$ & 10.3 \\
\hline 6 & 2 & Batang & $15,963,062,500$ & 28 \\
\hline 7 & 2 & Batang & $3,095,065,740$ & 5.4 \\
\hline 8 & 2 & Batang & $9,656,809,000$ & 16.9 \\
\hline 9 & 2 & Batang & $11,315,049,030$ & 19.8 \\
\hline \multicolumn{2}{|c|}{ Total } & & $56,997,420,260$ & 99.6 \\
\hline
\end{tabular}

Setelah perhitungan nilai penyerapan dana dan \% penyerapan dana maka semua nilai hasil perhitungan diurutkan berdasarkan nilai yang terbesar ke yang terkecil. Kemudian di lanjutkan dengan perhitungan \% kumulatif penyerapan dana, \% item jenis 
barang, \% kumulatif item jenis barang dan pemiliuhan katagori untuk masing-masing jenis item suku cadang. Hasil perhitungan selanjutnya dapat dilihat pada Tabel 12.

Tabel 12. Presentase Kumulatif Penyerapan Dana

\begin{tabular}{|c|c|c|c|c|c|c|}
\hline No. & Jenis Barang & $\begin{array}{c}\% \\
\text { Penyerapan } \\
\text { Dana (\%) }\end{array}$ & $\begin{array}{c}\% \\
\text { Kumulatif } \\
\text { Penyerapan } \\
\text { Dana }\end{array}$ & $\begin{array}{c}\% \\
\text { Item Jenis } \\
\text { Barang }\end{array}$ & $\begin{array}{c}\% \\
\text { Kumulatif } \\
\text { Jenis } \\
\text { Barang }\end{array}$ & $\begin{array}{c}\text { Katagori } \\
\text { Pemilihan } \\
\text { Metode } \\
\text { ABC }\end{array}$ \\
\hline 1 & 2 & 3 & 4 & 5 & 6 & 7 \\
\hline 1 & Rotan Semanow 24-29 & 28 & 28 & 11.11 & 11.11 & A \\
\hline 2 & Rotan Semanow 40 & 20 & 48 & 11.11 & 22.22 & A \\
\hline 3 & Rotan Semanow 35-39 & 17 & 65 & 11.11 & 33.33 & A \\
\hline 4 & Rotan Semanow 18-23 & 10 & 75 & 11.11 & 44.44 & A \\
\hline 5 & Rotan Lacak & 10 & 85 & 11.11 & 55.55 & B \\
\hline 6 & Rotan fega & 6 & 91 & 11.11 & 66.66 & B \\
\hline 7 & Rotan Semanow 30-34 & 5 & 96 & 11.11 & 77.77 & B \\
\hline 8 & Rotan Semanow 15-17 & 2 & 98 & 11.11 & 88.88 & C \\
\hline 9 & Rotan Semanow & 2 & 100 & 11.11 & 99.99 & C \\
\hline
\end{tabular}

\section{HASIL DAN PEMBAHASAN}

Hasil perhitungan dikelompokkan menjadi kelompok A,B dan C, dimana keterangannya sebagai berikut:

1. Kelompok A yaitu kelompok 50\% terbanyak nilai pemakaiannya.

2. Kelompok C yaitu kelompok $20 \%$ terendah nilai pemakaiaannya.

3. Kelompok B yaitu merupakan kelompok yang berada di tengah-tengah.

Pembagian pengelompokan tersebut yang perlu di perhatikan adalah jenis barang tipe A merupakan jenis barang yang sangat penting (memiliki nilai pemakaian terbesar), Sedangkan kelompok B merupakan posisi nomor dua dibawah kelompok A dan kelompok C merupakan kelompok yang relatif lebih kecil dari kelompok B.

\section{KESIMPULAN}

Adapun kesimpulan dari penelitian ini adalah:

1. Total persentase penyerapan dana sebesar $99,6 \%$.

2. Persen kumulatif item jenis barang, Rotan Semanow (24-29) 11,11\%, Rotan Semanow (40) 22,22 \%, Rotan Semanow (35-39) 33,33\%, Rotan Semanow (18-23) 44,44\%, Rotan Lacak 55,55 \%, Rotan Fega 66,66\%, Semanow (30-34) 77,77 \%, Semanow (15-17) 88,88\%, dan Rotan Semanow 99,99 \%.

3. Ada 4 item barang yang tergolong kedalam kelas A yaitu persediaan yang bernilai tinggi, persediaan yang bernilai sedang digolongkan kedalam kelas $\mathrm{B}$, dan persediaan yang bernilai rendah termasuk kedalam kelas C. Maka terdapat perbedaan kebijaksanaan persediaan untuk ketiga kelas ini, sehingga perusahaan dapat mengetahui berapa jumlah rotan yang dibutuhkan untuk setiap kategori penggolongan kebutuhan bahan baku rotan tersebut, dan pemesanan dapat dilakukan sesuai kebutuhan.

4. Invastasi harus ditekan untuk item persediaan kelas A dan B. dan item persediaan kelas $\mathrm{C}$ dengan pengendalian yang longgar untuk mengurangi resiko kehabisan persedian. 


\section{DAFTAR PUSTAKA}

[1] Eddy Herjanto. 1997. Manajemen Produksi dan Operasi, Edisi I. Penerbit: PT. Gramedia Widiasarana Indonesia, Jakarta.

[2] Freddy Rangkuti. 2002. Manajemen Persediaan Aplikasi Bidang Bisnis. Penerbit: PT Global Grafindo Persada, Jakarta.

[3] Senator Nur Bahagia. 2003. Sistem Inventory, Laboratorium Perencanaan Sistem Industri Departemen Teknik Industri, Institut Teknologi Bandung.

[4] Sofyan Assauri. 1993. Manajemen produksi, Penerbit: Fakultas Ekonomi Universitas Indonesia, Jakarta.

[5] Kusuma, H. 2004. Manajemen Produksi. Penerbit: Andi, Yogyakarta.

[6] Simamore, H. 1999. Akuntansi manajemen. Penerbit: Salembada Empat, Jakarta. 